\title{
PEKIŃSKA REFORMA LOTNICZEGO PRAWA KARNEGO - GENEZA, ISTOTA, REKOMENDACJE
}

Współcześnie nie ma chyba potrzeby przypominania ani opisywania, jak istotnym i brzemiennym w skutki problemem sa bezprawne akty wymierzone przeciwko lotnictwu cywilnemu. Zdarzenia te, w szczególności zaś wypadki zawładnięcia statkami powietrznymi, wywołują konsekwencje natury społecznej, ekonomicznej i politycznej, sięgające często daleko poza obszar samego lotnictwa ${ }^{1}$.

Aby wspomnianym zjawiskom przeciwdziałać, państwa podejmuja liczne wysiłki. W obszarze prawa sprowadzaja się one do stanowienia norm dotyczących ochrony lotnictwa (aviation security) oraz norm zaliczanych do lotniczego prawa karnego. Pierwsza grupa norm pełni funkcję zapobiegawcza. Zgodnie z definicją przyjętą przez Organizację Międzynarodowego Lotnictwa Cywilnego (International Civil Aviation Organization - ICAO) jej celem jest ochrona lotnictwa cywilnego przed aktami bezprawnej ingerencji, osiagana przez połączenie środków oraz zasobów ludzkich i materialnych ${ }^{2}$. Na płaszczyźnie międzynarodowej stosowne regulacje i wytyczne obejmuja przede wszystkim normy oraz zalecone metody postępowania określone w załączniku 17 do konwencji chicagowskiej, a także zalecenia zawarte w wydanym przez ICAO podręczniku bezpieczeństwa ${ }^{3}$. Sa one implementowane m.in. w aktach wydawanych na poziomie unijnym i krajowym ${ }^{4}$. Omawianie tych dokumentów wykracza poza ramy niniejszego artykułu ${ }^{5}$. W tym miejscu warto

1 Szerzej: Z. Galicki, Bezprawne zawtadnięcie statkiem powietrznym, „Sprawy Międzynarodowe” 1970, nr 7, s. 110; idem, Terroryzm lotniczy $w$ świetle prawa międzynarodowego, Warszawa 1981, s. 37-39; B. Nowak, Akty terroryzmu $w$ lotnictwie cywilnym a tokijsko-hasko-montrealski system międzynarodowego lotniczego prawa karnego, ,Studia Europejskie” 2003, nr 3, s. 122-123.

${ }^{2}$ Zob. rozdział 1 załącznika 17 (Dz. Urz. ULC 2011, nr 18, poz. 109) do Konwencji o międzynarodowym lotnictwie cywilnym, podpisanej w Chicago 7 grudnia 1944 r. (Dz. U. 1959, Nr 35, poz. 212 ze zm.; UNTS, vol. 15, no. 102; ICAO Doc 7300/9; dalej jako: konwencja chicagowska).

${ }^{3}$ Security Manual for Safeguarding Civil Aviation Against Acts of Unlawful Interference, ICAO Doc 8973.

${ }^{4}$ Zob. w szczególności rozporządzenie Parlamentu Europejskiego i Rady nr 300/2008/WE z 11 marca 2008 r. w sprawie wspólnych zasad w dziedzinie ochrony lotnictwa cywilnego i uchylające rozporządzenie nr 2320/2002/WE (Dz. Urz. L 2008, nr 97, s. 72-84 ze zm.) oraz dział IX ustawy z 3 lipca 2002 r. - Prawo lotnicze, Dz. U. 2012, poz. 933 ze zm. (dalej jako: Prawo lotnicze).

${ }^{5}$ Szerzej na temat przepisów dotyczących ochrony lotnictwa: M. Polkowska, Ochrona lotnictwa cywilnego przed terrorystami $w$ prawie miedzynarodowym i europejskim, ,Jurysta” 2006, nr 9; eadem, Suwerenność państwa w przestrzeni powietrznej. Geneza, zakres i ewolucja, Warszawa 2010, s. 225-236; M. Żylicz, Prawo lotnicze międzynarodowe, europejskie i krajowe, Warszawa 2011, s. 439-447. 
natomiast zwrócić uwagę, że ochrona lotnictwa nie stanowi wystarczającego zabezpieczenia przed aktami bezprawnej ingerencji przeciw lotnictwu cywilnemu. Dlatego jej oczywistym dopełnieniem jest stosowanie przez państwa sankcji karnej ${ }^{6}$.

\section{LOTNICZE PRAWO KARNE}

Niezależnie od niewątpliwych walorów prewencyjnych ${ }^{7}$ zasadniczym celem lotniczego prawa karnego jest ściganie i karanie sprawców przestępstw i wykroczeń związanych z działalnością lotnictwa ${ }^{8}$. Wartości chronione w obrębie tej gałęzi prawa sprowadzaja się przede wszystkim do bezpieczeństwa i porządku żeglugi powietrznej, suwerenności powietrznej państw oraz życia, zdrowia i mienia osób ${ }^{9}$. Odpowiadający im katalog celów przypisywanych lotniczemu prawu karnemu wykracza zatem poza samą ochronę przed bezprawnymi aktami skierowanymi przeciwko lotnictwu cywilnemu.

Jednakże to ta ostatnia kategoria stanowi trzon tego prawa oraz podstawowy obszar zainteresowania prawodawcy międzynarodowego. Łączy się ona ponadto z pojęciem zwalczania terroryzmu lotniczego, tj. aktów terroryzmu zagrażających bezpieczeństwu międzynarodowej żeglugi powietrznej ${ }^{10}$, stanowiących przestępstwa dokonywane z użyciem niebezpiecznych narzędzi lub materiałów, najczęściej przeciwko władzy lub w celu zastraszenia społeczeństwa przez spowodowanie śmierci, uszkodzenia ciała, ograniczenia wolności osób lub zniszczenia mienia ${ }^{11}$. W ramach niniejszych rozważań przejawy terroryzmu lotniczego można zatem określić jako szczególnego typu akty bezprawnej ingerencji przeciw lotnictwu cywilnemu, kwalifikowane ze względu na cel działania sprawców, którym jest wywołanie powszechnego strachu i poczucia zagrożenia ${ }^{12}$.

Struktura lotniczego prawa karnego odpowiada charakterystyce pozostałych gałęzi prawa lotniczego. Składa się na nią szczebel międzynarodowy, w tym przede wszystkim konwencje o zasięgu światowym. Na tej płaszczyźnie określone są w szczególności przestępstwa międzynarodowe (delicta iuris gentium), właściwość prawa, jurysdykcja karna oraz zasady ekstradycji. Umowy międzynarodowe $\mathrm{z}$ zakresu lotniczego prawa karnego podlegaja $\mathrm{w}$ Polsce ratyfikacji i po jej dokonaniu obowiązują również w porządku wewnętrznym. Przy czym, co do przestępstw prawa narodów, państwa zobowiązują się jedynie na podstawie umów międzynarodowych do ścigania i karania sprawców takich czynów.

\footnotetext{
${ }^{6}$ Akty bezprawnej ingerencji zostały zdefiniowane w załączniku 17 do konwencji chicagowskiej i sa pojęciem właściwym dla zagadnień związanych z ochroną lotnictwa. Pokrywają się one z licznymi przestępstwami przeciwko bezpieczeństwu lotnictwa omówionymi poniżej.

${ }^{7} \mathrm{~W}$ literaturze podkreśla się, że aż do czasów ataków w USA z 11 września 2001 r. przepisy lotniczego prawa karnego skutecznie przyczyniały się do ograniczenia liczby aktów przeciw bezpieczeństwu lotnictwa. Por.: B. Nowak, op. cit., s. 133-134; M. Żylicz, Prawo lotnicze..., s. 95.

${ }^{8}$ Por. M. Żylicz, Prawo lotnicze..., s. 448.

9 Tak ibidem.

10 Z. Galicki, Terroryzm lotniczy..., s. 32.

11 M. Żylicz, Terroryzm lotniczy, „Palestra” 2004, nr 3-4, s. 126.

12 Por. Z. Galicki, Terroryzm lotniczy..., s. 25-26; B. Nowak, op. cit., s. 118.
} 
Omawiane akty nie ustanawiaja w tym zakresie kompletnych norm prawa karnego nadających się do bezpośredniego stosowania w porządku krajowym.

Drugi szczebel lotniczego prawa karnego obejmuje prawo wewnętrzne. Tworzą go przepisy ustanawiające przestępstwa i wykroczenia ${ }^{13}$. Będą to zarówno przestępstwa zdefiniowane w Kodeksie karnym, jak i przestępstwa pozakodeksowe, w szczególności wskazane w dziale XII Prawa lotniczego. Czyny zabronione określone w prawie krajowym nie sa wynikiem bezpośredniego wdrożenia postanowień konwencji lotniczych, jednakże przyjęty w tym wypadku zakres kryminalizacji odpowiada w zasadzie treści przestępstw międzynarodowych ${ }^{14}$.

Z kolei znamienna dla innych działów prawa lotniczego płaszczyzna europejska ma w odniesieniu do prawa karnego niewielkie znaczenie ${ }^{15}$. Akty prawa Unii Europejskiej ograniczają się w zasadzie do zobowiązania państw członkowskich do karania osób naruszających poszczególne przepisy innych dziedzin tego prawa ${ }^{16}$. Oczywiście do ścigania przestępstw międzynarodowych przeciw bezpieczeństwu lotnictwa pomiędzy państwami członkowskimi znajdą zastosowanie także ogólne instytucje prawa europejskiego dotyczące współpracy w sprawach karnych.

Zasadnicze problemy lotniczego prawa karnego, wedle których przyjęło się omawiać akty tego prawa, sprowadzają się do zakresu kryminalizacji międzynarodowej, zakresu zastosowania przepisów konwencji, jurysdykcji państw oraz ekstradycji ${ }^{17}$. Metodologia ta zostanie poniżej zastosowana do omówienia aktualnych pryncypiów, a następnie założeń reformy pekińskiej.

\section{System tokijsko-hasko-montrealski}

Podstawowe znaczenie dla lotniczego prawa karnego maja uregulowania tzw. systemu tokijsko-hasko-montrealskiego. Składają się na niego trzy zawarte pod auspicjami ICAO konwencje międzynarodowe o niemal powszechnym zasięgu, które dotyczą przestępstw przeciwko lotnictwu cywilnemu.

Pierwszą historycznie międzynarodową inicjatywą legislacyjną poświęconą problemom karnego prawa lotniczego była Konwencja w sprawie przestępstw i niektórych innych czynów popełnionych na pokładzie statków powietrznych, sporządzona w Tokio 14 września 1963 r. ${ }^{18}$ Umowa ta była odpowiedzią na problemy dotyczące jurysdykcji i właściwości prawa karnego w zakresie

13 Por. M. Żylicz, Prawo lotnicze..., s. 448.

14 Zagadnienie to zostanie rozwinięte w dalszej części artykułu.

15 Jakkolwiek kompetencje Unii Europejskiej w tym obszarze pozwalają na przyjęcie aktów regulujących wiele spośród zagadnień należących do opisanego poniżej systemu lotniczego prawa karnego. Zob. art. 82-85 Traktatu o funkcjonowaniu Unii Europejskiej (Dz. Urz. C 2010, nr 83, s. 47-200).

${ }^{16}$ Szerzej M. Żylicz, Prawo lotnicze..., s. 454.

17 Por. Z. Galicki, Konwencja o zwalczaniu bezprawnego zawtadnięcia statkami powietrznymi, „Sprawy Międzynarodowe” 1971, nr 2; idem, Konwencja o zwalczaniu bezprawnych czynów przeciw bezpieczeństwu lotnictwa cywilnego, „Sprawy Międzynarodowe” 1971, nr 12.

${ }^{18}$ Dalej jako: konwencja tokijska z 1963 r. (Dz. U. 1971, Nr 15, poz. 147; UNTS, vol. 704, no. 10106; ICAO Doc 8364). 
związanym z lotnictwem ${ }^{19}$. Konwencja ta nie definiuje przestępstw międzynarodowych. Odnosi się ona jedynie do przestępstw określonych $\mathrm{w}$ prawie karnym oraz czynów, które niezależnie od tego, czy są przestępstwami, moga narażać lub narażają na niebezpieczeństwo statek powietrzny, osoby albo mienie znajdujące się na pokładzie, lub czynów, które naruszaja porządek i dyscyplinę na pokładzie.

Co do takich przestępstw i czynów popełnionych na pokładzie statku powietrznego konwencja tokijska przewiduje właściwość państwa rejestracji statku. W odniesieniu do przestępstw umowa ta dodatkowo zobowiązuje państwo rejestracji do podjęcia środków koniecznych do ustanowienia własnej jurysdykcji. Przy tym akt ten nie wyklucza wykonywania innej jurysdykcji karnej zgodnie $\mathrm{z}$ prawem krajowym. Konwencję stosuje się $\mathrm{w}$ zasadzie do przestępstw lub czynów popełnionych przez osobę na pokładzie statku powietrznego zarejestrowanego $\mathrm{w}$ państwie stronie w czasie lotu statku bądź gdy znajduje się on na powierzchni morza pełnego lub obszaru leżącego poza terytorium jakiegokolwiek państwa. W zakresie ekstradycji akt ten stanowi jedynie, że przestępstwa popełnione na pokładzie statku powietrznego zarejestrowanego w państwie stronie uważa się dla celów ekstradycji za popełnione także na terytorium państwa rejestracji statku powietrznego.

Konwencja tokijska zawiera ponadto szereg innych ustaleń dotyczących uprawnień dowódcy statku powietrznego oraz praw i obowiązków państw w wypadku przestępstw lub czynów na pokładzie statku powietrznego. Dlatego postanowienia tej umowy sytuuje się niekiedy na pograniczu prawa karnego i ochrony lotnictwa ${ }^{20}$.

Za mankament konwencji tokijskiej uznawano brak międzynarodowej podstawy bezprawności, tj. międzynarodowej definicji przestępstwa ${ }^{21}$. W odniesieniu do najbardziej palącego problemu uprowadzeń statków powietrznych (hijacking) - rozwiązaniem stała się przyjęta w Hadze 16 grudnia 1970 r. Konwencja o zwalczaniu bezprawnego zawładnięcia statkami powietrznymi ${ }^{22}$. Po raz pierwszy w prawie lotniczym zdefiniowano przestępstwo międzynarodowe polegające na zawładnięciu statkiem powietrznym lub przejęciu nad nim kontroli przez osobę znajdującą się na pokładzie statku powietrznego będącego w locie ${ }^{23}$, działającą bezprawnie, przemoca ${ }^{24}$ lub groźbą użycia przemocy lub w każdej innej formie zastraszenia. Przestępstwem jest ponadto usiłowanie i współsprawstwo. Państwa strony przyjęły na siebie zobowiązanie surowego karania sprawców takich czynów.

${ }^{19}$ Szerzej: I. H. Ph. Diederiks-Verschoor, An Introduction to Air Law, Kluwer Law International 2006, s. 289-293; M. Żylicz, Prawo lotnicze..., s. 96.

${ }^{20}$ Systematykę taką przyjmuje M. Żylicz, por. idem, Prawo lotnicze..., s. 95 i 444-445.

${ }^{21}$ I. H. Ph. Diederiks-Verschoor, op. cit., s. 298; Z. Galicki, Bezprawne zawtadnięcie..., s. 116.

${ }^{22}$ Dalej jako: konwencja haska z 1970 r. (Dz. U. 1972, Nr 25, poz. 181; UNTS, vol. 860, no. 12325; ICAO Doc 8920).

${ }^{23}$ Lot trwa od chwili, gdy załadowanie zostało zakończone i wszystkie drzwi zewnętrzne zostały zamknięte, aż do chwili, gdy jedne $\mathrm{z}$ tych drzwi zostały otwarte $\mathrm{w}$ celu wyładowania. W wypadku przymusowego lądowania przyjmuje się, że lot trwa nadal aż do chwili przejęcia przez właściwe władze odpowiedzialności za statek powietrzny oraz osoby i mienie znajdujące się na pokładzie (art. 3 ust. 1 konwencji haskiej z 1970 r.).

${ }^{24}$ Przemoc należy w tym wypadku rozumieć szeroko, jako wszelkie jej przejawy, w tym przemoc fizyczna, psychiczną oraz inne jej formy, zob. Z Galicki, Terroryzm lotniczy..., s. 69-70. 
Konwencja znajduje zasadniczo zastosowanie, gdy miejsce startu lub miejsce rzeczywistego lądowania statku powietrznego, na pokładzie którego przestępstwo zostało popełnione, jest położone poza terytorium państwa rejestracji statku. Co do ścigania, ekstradycji i pomocy prawnej, konwencję stosuje się także, jeżeli sprawca przestępstwa znalazł się na terytorium państwa innego niż państwo rejestracji statku. Przewiduje ona obowiązek ustanowienia jurysdykcji przez państwo rejestracji statku powietrznego, państwo, na terytorium którego ląduje ze sprawca na pokładzie statek powietrzny, na pokładzie którego popełniono przestępstwo, a w wypadku dzierżawy statku bez załogi - państwo głównego miejsca działalności lub stałego pobytu dzierżawcy.

W konwencji haskiej z 1970 r. zrealizowano koncepcję represji wszechświatowej. Zobowiązanie do ustanowienia jurysdykcji dotyczy bowiem także wypadku, gdy sprawca przestępstwa znajduje się na terytorium państwa, a ono nie wydaje go żadnemu $\mathrm{z}$ państw, które wykonuja jurysdykcję $\mathrm{w}$ myśl przytoczonych wyżej reguł. $\mathrm{Z}$ powyższą zasadą jurysdykcji uniwersalnej wiąże się obowiązek wydania sprawcy lub przeprowadzenia postępowania karnego (aut dedere aut iudicare). Natomiast sama ekstradycja odbywa się na podstawie przepisów krajowych i odrębnych umów ${ }^{25}$ lub - w braku takich umów - fakultatywnie na podstawie konwencji. Nie przewidziano przy tym obowiązku ekstradycji ${ }^{26}$. Hijacking uznaje się za przestępstwo uzasadniające ekstradycje i traktuje jako dokonane zarówno w miejscu jego popełnienia, jak i na terytorium państw zobowiązanych do ustanowienia swej jurysdykcji. Państwa maja obowiązek traktować to przestępstwo jak każde przestępstwo pospolite o poważnym charakterze ${ }^{27}$.

Ponieważ konwencja haska z 1970 r. dotyczyła jedynie przestępstwa uprowadzenia statku powietrznego, konieczne było poszerzenie zakresu przestępstw międzynarodowych naruszających bezpieczeństwo lotnictwa cywilnego. W tym celu 23 września $1971 \mathrm{r}$. sporządzona została w Montrealu Konwencja o zwalczaniu bezprawnych czynów skierowanych przeciwko bezpieczeństwu lotnictwa cywilnego ${ }^{28}$. Kryminalizuje ona wiele czynów, które moga zagrażać bezpieczeństwu statków powietrznych i co do których państwa strony przyjęły na siebie zobowiązanie surowego karania ich sprawców. Należą do nich akty przemocy wobec osoby znajdującej się na pokładzie statku powietrznego w locie, niszczenie lub uszkadzanie statku powietrznego w służbie ${ }^{29}$, umieszczanie na

${ }^{25}$ Zob. w szczególności Europejska konwencja o ekstradycji, sporządzona w Paryżu 13 grudnia 1957 r. (CETS no. 024; UNTS, vol. 359, No. 5146) wraz z protokołami dodatkowymi z 15 października 1975 r. (CETS no. 086; UNTS, vol. 1161, No. 5146), z 17 marca 1978 r. (CETS no. 098; UNTS, vol. 1496, no. 5146) -Dz. U. 1994, Nr 70, poz. 307 - oraz Protokołem z 10 listopada 2010 r. (CETS No. 209), w Polsce jeszcze nieratyfikowanym.

${ }^{26}$ Co do dokonania ekstradycji rozstrzygające jest zatem prawo krajowe, z tym że stosowny obowiązek może wynikać z innych aktów prawnych, w szczególności Europejskiej konwencji o ekstradycji.

${ }^{27}$ Szerzej na temat konwencji haskiej z 1970 r. zob.: I. H. Ph. Diederiks-Verschoor, op. cit., s. 298-303; Z. Galicki, Konwencja o zwalczaniu bezprawnego zawtadnięcia...; idem, Terroryzm lotniczy...; B. Nowak, Problemy bezpieczeństwa $w$ międzynarodowym lotnictwie cywilnym $w$ świetle konwencji haskiej 1970 z roku, „Studia Europejskie” 2001, nr 3; idem, Akty terroryzmu...; J. Rajski: Konwencja haska o zwalczaniu bezprawnego zawtadnięcia statkami powietrznymi, „Państwo i Prawo” 1971, z. 5.

28 Dalej jako: konwencja montrealska z 1971 r. (Dz. U. 1976, Nr 8, poz. 37; UNTS, vol. 974, no. 14118; ICAO Doc 8966).

${ }^{29}$ Konwencja posługuje się pojęciami ,statek w locie”, rozumianym jak w konwencji haskiej 
statku powietrznym w służbie urządzeń lub substancji, które mogą ten statek zniszczyć albo spowodować jego uszkodzenie, niszczenie lub uszkadzanie lotniczych urządzeń nawigacyjnych lub zakłócanie ich działania, przekazywanie fałszywych informacji stwarzających zagrożenie bezpieczeństwa statku powietrznego w locie. Przestępstwem jest również usiłowanie i współsprawstwo.

Przyjęto analogiczny do konwencji haskiej z 1970 r. zakres zastosowania konwencji, rozszerzony jednak o wypadki, gdy przestępstwo zostało popełnione na terytorium państwa innego niż państwo rejestracji statku powietrznego ${ }^{30}$, co do czynów przeciw urządzeniom nawigacyjnym ograniczone zaś wymogiem wykorzystania tych urządzeń w międzynarodowej żegludze powietrznej. W stosunku do konwencji haskiej z $1970 \mathrm{r}$. obowiązek ustanowienia jurysdykcji został poszerzony o państwo, na terytorium którego popełnione zostało przestępstwo. Kwestię jurysdykcji uniwersalnej i ekstradycji potraktowano tak jak w konwencji haskiej z $1970 \mathrm{r} .{ }^{31}$

Po atakach terrorystycznych $\mathrm{w}$ międzynarodowych portach lotniczych w Rzymie i w Wiedniu w 1985 r. konwencja montrealska z 1971 r. została zmodyfikowana protokołem z $1988 \mathrm{rr}^{32}$, w Polsce ratyfikowanym dopiero w 11 września 2004 r. ${ }^{33}$ Uznaje on za przestępstwo (dokonany bezprawnie i umyślnie z użyciem jakiegokolwiek urządzenia, substancji lub broni) akt przemocy skierowany przeciwko osobie $\mathrm{w}$ porcie lotniczym obsługującym międzynarodowe lotnictwo cywilne, który powoduje lub stwarza zagrożenie poważnego uszkodzenia ciała lub śmierć tej osoby, albo akt powodujący niszczenie lub poważnie uszkodzenie urządzenia w porcie lotniczym obsługującym międzynarodowe lotnictwo cywilne lub statku powietrznego poza służba znajdującego się $\mathrm{w}$ porcie lub powodujący przerwę $\mathrm{w}$ działalności tego portu lotniczego. Do przestępstw określonych w protokole stosuje się zasady konwencji montrealskiej z 1971 r., z wyjątkiem ograniczeń przedmiotowego zakresu zastosowania konwencji.

\section{Pozostałe akty prawne}

Na kształt prawa karnego w obszarze dotyczącym lotnictwa cywilnego wpływaja też akty nienależące do systemu tokijsko-hasko-montrealskiego. Trzeba tu wskazać na wzmiankowane umowy międzynarodowe dotyczące

z 1970 r., oraz ,statek w służbie”, co oznacza statek od chwili, w której personel naziemny lub załoga rozpoczyna przygotowywanie go do określonego lotu, aż do upływu dwudziestu czterech godzin po każdym lądowaniu, w tym cały okres, w ciągu którego statek powietrzny jest w locie (art. 2 konwencji montrealskiej z $1971 \mathrm{r}$.).

${ }^{30}$ Co jest konsekwencją faktu, że przestępstwa z konwencji montrealskiej dotyczą nie tylko statków w locie, lecz także w służbie.

${ }^{31}$ Szerzej na temat konwencji montrealskiej z 1971 r. zob.: I. H. Ph. Diederiks-Verschoor, op. cit., s. 303-308; Z. Galicki, Konwencja o zwalczaniu bezprawnych czynów...; idem, Terroryzm lotniczy...; B. Nowak, Akty terroryzmu...

${ }^{32}$ Protokół o zwalczaniu bezprawnych czynów przemocy w portach lotniczych obsługujących międzynarodowe lotnictwo cywilne, sporządzony w Montrealu 24 lutego 1988 r., uzupełniający Konwencję o zwalczaniu bezprawnych czynów skierowanych przeciwko bezpieczeństwu lotnictwa cywilnego podpisaną w Montrealu 23 września 1971 r. (dalej jako: protokół montrealski z 1988 r.; UNTS, vol. 1589, no. 14118; ICAO Doc 9518).

${ }^{33}$ Dz. U. 2006, Nr 48, poz. 348. 
ekstradycji, a także na porozumienia o pomocy prawnej w sprawach karnych czy też regulacje odnoszące się do zwalczania terroryzmu ${ }^{34}$.

Podstawowe znaczenie dla stosowania systemu tokijsko-hasko-montrealskiego będzie jednak miało prawo krajowe. Przed omówieniem zmian zaproponowanych podczas konferencji pekińskiej z 2010 r. warto pokrótce przeanalizować, w jakim zakresie realizuje ono jego założenia.

Można przyjąć, że omówione powyżej zobowiązania międzynarodowe do ustanowienia własnej jurysdykcji zostały przez Polskę spełnione. Służą im przepisy dotyczące właściwości prawa zawarte w art. 5 i art. 113 k.k. oraz w art. 9 Prawa lotniczego. Z kolei dyspozycje przestępstw międzynarodowych pokrywają się z różnymi przestępstwami zdefiniowanymi w Kodeksie karnym, w szczególności w jego rozdziałach XIX (przestępstwa przeciwko życiu i zdrowiu), XX (przestępstwa przeciwko bezpieczeństwu powszechnemu) i XXI (przestępstwa przeciwko bezpieczeństwu w komunikacji), XXIII (przestępstwa przeciwko wolności), a także przestępstwami określonymi w art. 212 ust. 1 pkt 3, 5 i 6 Prawa lotniczego, które podlegają w zasadzie surowym karom ${ }^{35}$.

\section{REFORMA PEKIŃSKA}

Przez kilkadziesiąt lat funkcjonowania systemu tokijsko-hasko-montrealskiego zmieniły się zagrożenia bezpieczeństwa lotnictwa cywilnego. Pojawiły się inne sposoby działania przestępców, wsparte nowymi możliwościami technicznymi. Terroryzm lotniczy pokazał nieznane dotąd oblicze w atakach $\mathrm{z} 11$ września 2001 r. w Stanach Zjednoczonych. Konieczne stało się uwzględnienie nowych niebezpieczeństw w ramach systemu lotniczego prawa karnego i ochrony lotnictwa ${ }^{36}$. Podjęcie stosownych działań w kierunku rewizji prawa ICAO zaleciła już w 2001 r. ${ }^{37} \mathrm{~W} 2007$ r. komitet prawny ICAO powołał grupę mająca na celu opracowanie założeń modernizacji systemu ${ }^{38}$, a w 2009 r. przedłożył propozycje zmian konwencji haskiej z 1970 r. i konwencji montrealskiej z $1971 \mathrm{r}^{39}$ Projekty te stały się podstawą do dalszych prac uwieńczonych przyjęciem 10 września 2010 r., podczas konferencji odbywającej się w Pekinie, konwencji o zwalczaniu bezprawnych aktów dotyczących lotnictwa cywilnego ${ }^{40}$ oraz protokołu dodatkowego do konwencji haskiej z 1970 r. $^{41}$

Warto zaznaczyć, że zmianom wprowadzonym w powyższych dokumentach towarzyszą też działania ICAO służące wzmocnieniu ochrony lotnictwa. Należy

${ }^{34}$ Przegląd i podsumowanie postanowień aktualnych aktów prawa międzynarodowego z zakresu zwalczania terroryzmu, zob. B. Hołyst, Terroryzm, t. 2, Warszawa 2011, s. 1125-1141.

${ }^{35} \mathrm{O}$ odpowiednich wypadkach znajdzie ponadto zastosowanie przepis art. $65 \S 1 \mathrm{k} . \mathrm{k}$., przewidujący zaostrzenie wymiaru kary w odniesieniu do sprawców przestępstw o charakterze terrorystycznym.

${ }^{36}$ Por. The 2010 Beijing Convention and Protocol: Ushering in a New Legal Era for Aviation, „ICAO Journal" 2011, nr 1, s. 11-12.

${ }^{37}$ Zob. pkt 7 uchwały A33-1 Zgromadzenia ICAO (ICAO Doc 9958).

${ }^{38}$ Special Sub-Committee on the Preparation of One or More Instruments Addressing New and Emerging Threats.

${ }^{39}$ Draft Report on the Work of the Legal Committee During its 34th Session, LC/34-WP/5-3.

${ }^{40}$ Dalej jako: konwencja pekińska (ICAO Doc 9960).

${ }^{41}$ Dalej jako: protokół pekiński (ICAO Doc 9959). 
w szczególności wskazać na ostatnie poprawki załącznika 17 do konwencji chicagowskiej $^{42}$ oraz na rekomendacje zawarte w deklaracji w sprawie ochrony lotnictwa z $2010 \mathrm{r.}^{43}$

\section{Konwencja pekińska}

Konwencja pekińska ma na celu zastąpienie konwencji montrealskiej z 1971 r., zmienionej protokołem z 1988 r., i między stronami znajdzie ona pierwszeństwo zastosowania przed tymi aktami. Do czasu przyjęcia konwencji pekińskiej przez wszystkie państwa strony konwencji montrealskiej ta ostatnia wciąż będzie znajdować zastosowanie. Dlatego M. Żylicz mówi obecnie o systemie tokijsko-hasko-montrealsko-pekińskim ${ }^{44}$.

Podstawową różnicą konwencji pekińskiej w stosunku do jej poprzedniczki jest znaczące rozszerzenie zakresu przestępstw międzynarodowych. Dotyczy to zarówno strony przedmiotowej, jak i podmiotowej tych przestępstw, a także ich form i służy objęciu przepisami konwencji możliwie szerokiego zakresu działań związanych z terroryzmem międzynarodowym. Przy czym, podobnie jak w dotychczasowym systemie, konwencja nie ustanawia co do zdefiniowanych w niej przestępstw kompletnych norm prawa karnego. Natomiast państwa zobowiązują się do stosowania w porządku wewnętrznym surowych kar wobec sprawców tych czynów.

Oprócz powtórzonych w niej przestępstw, znanych z konwencji montrealskiej z 1971 r. ${ }^{45}$ oraz protokołu z 1988 r. $^{46}$, konwencja pekińska kryminalizuje dodatkowo użycie statku powietrznego w celu spowodowania śmierci, poważnego uszkodzenia ciała, poważnej szkody na mieniu lub środowisku, a także zrzucenie lub odpalenie ze statku powietrznego w służbie (albo użycie na pokładzie takiego statku) broni biologicznej, chemicznej lub atomowej albo materiału wybuchowego, radioaktywnego lub podobnego w sposób powodujący lub mogący spowodować śmierć, poważne obrażenia, poważną szkodę na mieniu

\footnotetext{
${ }^{42}$ Por. wyd. 8 (Dz. Urz. ULC 2010, nr 18, poz. 93) i wyd. 9 (Dz. Urz. ULC 2011, nr 18, poz. 109) załącznika 17.

${ }^{43}$ ICAO Assembly Declaration on Aviation Security, załącznik do uchwały A37-17 Zgromadzenia ICAO (ICAO Doc 9958).

${ }^{44}$ M. Żylicz, Prawo lotnicze..., s. 95.

${ }^{45} \mathrm{~W}$ tym zakresie konwencja pekińska poszerza przestępstwo niszczenia, uszkadzania lub zakłócania lotniczych urządzeń nawigacyjnych, zalicza bowiem do tych urządzeń także sygnały, dane, informacje lub systemy niezbędne dla nawigacji statków powietrznych. Jest to odpowiedzią na zagrożenia związane z cyberprzestępczością. Przy czym nadal czyn ten jest kryminalizowany jedynie wówczas, gdy zagraża bezpieczeństwu statku powietrznego w locie. Jest to wskazywane jako mankament konwencji, ponieważ wyłącza spod ochrony karnoprawnej np. statki powietrzne w trakcie rozładunku, zob. R. Abeyratne, The Beijing Convention of 2010 on the Suppression of Unlawful Acts Relating to International Civil Aviation: An Interpretative Study, „Journal of Transportation Security” 2011, nr 2, s. 137. Podobne uwagi autor ten odnosi do przestępstwa przekazywania fałszywych informacji, zob. ibidem, s. 138 .

${ }^{46} \mathrm{~W}$ konwencji przejęto wprost określenia przestępstw międzynarodowych znanych z protokołu montrealskiego z 1988 r. Jako niedociagnnięcie konwencji wskazuje się, że utrzymuje ona wymóg, aby przestępstwa te zagrażały bezpieczeństwu na lotniskach (pomija zaś zagrożenie bezpieczeństwa samych lotnisk), zob. ibidem, s. 140.
} 
lub środowisku ${ }^{47}$. W odniesieniu do powyższych czynów konwencja pekińska przewiduje po raz pierwszy, że przestępstwem jest sama groźba ich dokonania lub bezprawne i umyślne przekazanie takiej groźby jakiejkolwiek osobie, jeśli okoliczności sprawy wskazują, że groźba ta jest realna.

Ponadto za przestępstwo uznano też inne czyny, które są nie tylko skierowane bezpośrednio przeciwko bezpieczeństwu lotnictwa cywilnego, lecz także służą innym działaniom przestępczym, w szczególności o charakterze terrorystycznym. Wymienia się tu przewożenie oraz powodowanie lub ułatwianie przewożenia na pokładzie statku powietrznego materiałów wybuchowych lub radioaktywnych, jeśli wiadomo, że mają zostać użyte, aby spowodować lub wywołać groźbę spowodowania śmierci, poważnych obrażeń lub szkody w celu zastraszenia społeczeństwa lub zmuszenia władzy państwowej lub organizacji międzynarodowej do określonego działania lub do powstrzymania się od określonego działania. Przestępstwem wedle konwencji jest także przewożenie oraz powodowanie lub ułatwianie przewożenia broni biologicznej, chemicznej lub atomowej (ze świadomością, że jest to taka broń), ponadto jakiegokolwiek materiału rozszczepialnego albo wyposażenia lub materiału przeznaczonego do obróbki, użycia lub produkcji takiego materiału, jeśli sprawca ma świadomość zamiaru wykorzystania tego materiału jako ładunku nuklearnego lub w innej działalności nuklearnej nieobjętej ochroną Międzynarodowej Agencji Energii Atomowej, a także jakiegokolwiek wyposażenia, materiału, oprogramowania lub powiązanej technologii, która znacząco przyczynia się do projektowania, produkcji lub dostarczania broni biologicznej, chemicznej lub atomowej, bez stosowanego pozwolenia i ze świadomościa, że będzie wykorzystana w takim celu. Powyższe przestępstwa nie dotyczą działań państw lub osób działających z ich upoważnienia, w granicach dopuszczonych prawem międzynarodowym ${ }^{48}$.

Konwencja pekińska przewiduje nowe formy zjawiskowe zdefiniowanych $\mathrm{w}$ niej przestępstw (lub usiłowania popełnienia tych przestępstw). Poza współsprawstwem obecnie jest to również organizowanie innych osób w celu popełnienia przestępstwa i sprawstwo kierownicze. Przewidziano ponadto specyficzny rodzaj pomocnictwa polegający na przyczynieniu się w jakikolwiek sposób do popełnienia przestępstwa (niezależnie od tego, czy faktycznie zostało ono popełnione) przez grupę osób działających zgodnie ze wspólnym zamiarem bądź to w celu wsparcia ogólnej działalności przestępczej grupy, jeśli obejmuje ona przestępstwa określone w konwencji, bądź to ze świadomością zamiaru grupy dotyczącego popełnienia takiego przestępstwa. Nowa formą stadialną przestępstw z konwencji pekińskiej jest z kolei wejście w porozumienie w celu

\footnotetext{
${ }^{47}$ Analogiczne przykłady karnoprawnej ochrony środowiska występują już w innych aktach prawa międzynarodowego, zob. ibidem, s. 139.

${ }^{48}$ W szczególności postanowieniami: Układu o nierozprzestrzenianiu broni jądrowej, sporządzonego w Moskwie, Waszyngtonie i Londynie 1 lipca 1968 r. (Dz. U. 1970, Nr 8, poz. 60; UNTS, vol. 729, no. 10485); Konwencji o zakazie prowadzenia badań, produkcji i gromadzenia zapasów broni bakteriologicznej (biologicznej) i toksycznej oraz o ich zniszczeniu, sporządzonego w Moskwie, Londynie i Waszyngtonie 10 kwietnia 1972 r. (Dz. U. 1976, Nr 1, poz. 1; UNTS, vol. 1015, no. 14860); Konwencji o zakazie prowadzenia badań, produkcji, składowania i użycia broni chemicznej oraz o zniszczeniu jej zapasów, sporządzonej w Paryżu 13 stycznia 1993 r. (Dz. U. 1999, Nr 63, poz. 703; UNTS, vol. 1974, no. 33757).
} 
popełnienia któregokolwiek z takich przestępstw. Za przestępstwo uznano ponadto poplecznictwo na rzecz sprawców wskazanych w konwencji czynów zabronionych.

W porównaniu z konwencją montrealską z 1971 r. omawiana konwencja poszerza zakres podmiotowy przestępstw. Przewiduje ona, że państwo stronaniezależnie od odpowiedzialności karnej osób fizycznych - może wprowadzić odpowiedzialność karną, cywilną lub administracyjna podmiotów prawa utworzonych zgodnie $\mathrm{z}$ jego prawem lub umiejscowionych na jego terytorium, jeżeli osoba odpowiedzialna za zarządzanie lub wykonywanie kontroli nad takim podmiotem dopuściła się $\mathrm{w}$ związku $\mathrm{z}$ pełnieniem takiej funkcji pewnych przestępstw określonych w konwencji ${ }^{49}$. Odpowiednie sankcje powinny być efektywne, proporcjonalne i odstraszające.

Kwestia przedmiotowego zakresu stosowania konwencji została uregulowana analogicznie do obowiązujących dotychczas aktów. Natomiast w stosunku do zasad jurysdykcji znanych w systemie tokijsko-hasko-montrealskim konwencja pekińska nakłada na państwa strony dodatkowo obowiązek wprowadzenia jurysdykcji państwa obywatelstwa sprawcy, a ponadto zezwala na ustanowienie jurysdykcji państwa obywatelstwa ofiary przestępstwa lub państwa stałego miejsca zamieszkania sprawcy będącego bezpaństwowcem ${ }^{50}$. W konwencji podkreślono też, że nie wpływa ona na stosowanie innych umów międzynarodowych.

Za konwencją montrealską z 1971 r. powtórzono wymóg zapobiegania zdefiniowanym przestępstwom międzynarodowym. Dodatkowo nałożono na państwa strony obowiązek informowania o podejrzeniu, że przestępstwo zostanie popełnione, tych państw, które moga zgodnie z konwencją wykonywać swojąjurysdykcję w razie ich popełnienia. Odnośnie do ekstradycji zastosowano znane dotychczas rozwiązania. Jednocześnie omawiany akt precyzuje, że dla celów ekstradycji i pomocy prawnej przestępstwa w nim określone nie mogą być traktowane jako polityczne, związane z przestępstwami politycznymi lub oparte na motywach politycznych ${ }^{51}$. Konwencja pekińska zawiera ponadto gwarancje odpowiedniego traktowania osób, w stosunku do których toczy się postępowanie karne, w tym stosowania praw człowieka. Ponadto zgodnie z umową żadne z jej postanowień nie może być interpretowane jako zobowiązujące państwo do wydania osoby (lub do zapewnienia pomocy prawnej) w sytuacji, gdy istnieja istotne podstawy, aby przyjąć, że odpowiednie żądanie drugiego państwa zmierza do ścigania lub ukarania tej osoby $\mathrm{z}$ powodu jej rasy, wyznania, narodowości, pochodzenia, opinii politycznych czy płci lub pozwoli na dyskryminację tej osoby z wymienionych względów.

\footnotetext{
${ }^{49}$ Dotyczy to umyślnego dokonania przestępstwa w zakresie zwykłego sprawstwa, z wyłączeniem przestępstw przeciw bezpieczeństwu portów lotniczych.

${ }^{50}$ Ustanowienie tych jurysdykcji wymaga notyfikacji przy przystąpieniu do konwencji.

${ }^{51}$ Analogiczne postanowienie zawierała już Europejska konwencja o zwalczaniu terroryzmu, sporządzona w Strasburgu 27 stycznia 1977 r. (Dz. U. 1996, Nr 117, poz. 557; CETS No. 090; UNTS, vol. 1137, no. 17828). W konwencji pekińskiej klauzula taka po raz pierwszy wprowadzona została do międzynarodowego lotniczego prawa karnego. W omówionych wcześniej konwencjach występował jedynie wymóg traktowania w postępowaniu karnym zdefiniowanych w tych aktach przestępstw międzynarodowych jako przestępstw pospolitych o poważnym charakterze (utrzymany także w konwencji pekińskiej).
} 


\section{Protokół pekiński}

Drugi z aktów przyjętych podczas konferencji w 2010 r. - tzw. protokół pekiński - modyfikuje postanowienia konwencji haskiej z 1970 r. Podstawowa zmiana dotyczy nowej definicji przestępstwa. Obecnie popełnia je ten, kto bezprawnie i umyślnie przejmuje lub wykonuje kontrolę nad statkiem powietrznym w służbie za pomocą przemocy lub groźby jej użycia, przymusu lub innej formy zastraszenia lub za pomoca środków technicznych.

Strona przedmiotowa przestępstwa uległa zatem rozszerzeniu. Statek powietrzny musi znajdować się w służbie, a nie jak dotychczas w locie (co jest kategoria węższą). Miejsce popełnienia przestępstwa nie jest już ograniczone do pokładu statku powietrznego ${ }^{52}$. Kryminalizacja dotyczy już nie tylko przejęcia, lecz także wykonywania kontroli. Przestępstwo może zostać dokonane z wykorzystaniem różnych form przemocy, a także środków technicznych. W tym kontekście konieczne stało się sprecyzowanie strony podmiotowej przez dodanie przesłanki winy umyślnej. Przestępczość groźby popełnienia czynu została uregulowana analogicznie do konwencji pekińskiej. To samo dotyczy usiłowania, współsprawstwa, pomocnictwa oraz poplecznictwa.

Należy z aprobatą odnotować fakt, że protokół dąży do standaryzacji i uproszczenia systemu lotniczego prawa karnego. Modyfikuje on treść konwencji haskiej z 1970 r. w kierunku zapewnienia jej spójności z konwencja pekińską. W ten sam sposób unormowano w protokole i konwencji pekińskiej, m.in.: stosunek do innych uregulowań prawa międzynarodowego ${ }^{53}$, problemy jurysdykcji i ekstradycji, gwarancje odpowiedniego traktowania, obowiązki informacyjne. Ujednolicono także terminologię aktów. Natomiast nie wprowadzono do konwencji haskiej z 1971 r. postanowień regulujących zasady odpowiedzialności cywilnej w związku z uprowadzeniem statku powietrznego ${ }^{54}$.

Zgodnie z aktualną tendencją właściwą większości umów międzynarodowych w obszarze prawa lotniczego depozytariuszem konwencji pekińskiej oraz protokołu pekińskiego wyznaczona została ICAO, co powinno zapewnić

${ }^{52}$ Ograniczenie to było jednym z podstawowych mankamentów konwencji haskiej z $1970 \mathrm{r}$. w jej oryginalnym brzmieniu. Od dawna wskazywano ten problem w literaturze przedmiotu, zob. Z. Galicki, Konwencja o zwalczaniu bezprawnych czynów..., s. 88.

${ }^{53}$ Postanowienia te są częściowo zapożyczone $\mathrm{z}$ innych aktów prawa międzynarodowego, zob. S. Witten, Introductory Note to the Convention on the Suppression of Unlawful Acts Relating to International Civil Aviation and the Protocol Supplementary to the Convention for the Suppression of Unlawful Seizure of Aircraft, ,International Legal Materials” 2011, nr 2, s. 142.

${ }^{54}$ Problem wynagrodzenia szkód w związku z aktami bezprawnej ingerencji, o których mowa w konwencji haskiej z 1970 r. i konwencji montrealskiej z 1971 r., reguluje odrębna, przygotowana przez ICAO, Konwencja dotycząca odszkodowań za szkody wyrządzone osobom trzecim, będące skutkiem bezprawnych czynów przy użyciu statków powietrznych, podpisana w Montrealu 2 maja 2009 r. (ICAO Doc 9920). Konwencja ta oczekuje na wejście w życie. Obecnie w braku odpowiednich postanowień zastosowanie znaleźć muszą ogólne zasady wyrażone w lotniczym prawie prywatnym, w szczególności w Konwencji o ujednostajnieniu niektórych prawideł dotyczących międzynarodowego przewozu lotniczego, podpisanej w Warszawie 12 października 1929 r. (Dz. U. 1933, Nr 8, poz. 49 ze zm.; LNTS vol. 137, no. 3145; ICAO Doc 7838, 9201), wraz z aktami zmieniajacymi, oraz w Konwencji o ujednoliceniu niektórych prawideł dotyczących międzynarodowego przewozu lotniczego, podpisanej w Montrealu 28 maja 1999 r. (Dz. U. 2007, Nr 37, poz. 235; UNTS, vol. 2242, no. 39917; ICAO Doc 9740). Konieczność stosowania systemu warszawsko-montrealskiego wskazywana jest w literaturze jako mankament konwencji haskiej z 1970 r., zob. I. H. Ph. Diederiks-Verschoor, op. cit., s. 303. 
wszystkim zainteresowanym państwom możliwość przystąpienia do tych porozumień. Zrezygnowano zatem $\mathrm{z}$ zastosowanej $\mathrm{w}$ omówionych poprzednio konwencjach praktyki wyznaczenia trzech depozytariuszy ${ }^{55}$.

\section{REKOMENDACJE DLA POLSKI}

Reformę lotniczego prawa karnego można odnotować jako krok pozytywny, dostosowujący stan prawny do zmiany zagrożeń dla lotnictwa cywilnego, w tym ich uwarunkowań technologicznych, a ponadto usuwający dotychczasowe niedostatki przepisów i porządkujący system tego prawa. W tym miejscu wypada przyłączyć się do zalecenia ICAO $^{56}$ i rekomendować ratyfikację obu aktów przez Polskę. Konwencja i protokół wejdą w życie po złożeniu dwudziestego drugiego instrumentu ratyfikacji.

$\mathrm{W}$ razie przyjęcia konwencji - ze względu na poszerzenie zakresu przestępstw międzynarodowych - w porządku krajowym oprócz omówionych powyżej przepisów Kodeksu karnego znajdą dodatkowo zastosowanie przepisy jego rozdziału XXII (przestępstwa przeciwko środowisku). Jeśli uwzględnić przepisy dotyczące form popełnienia przestępstwa oraz przepisy części szczególnej Kodeksu karnego, przyjęcie konwencji pekińskiej będzie jednak wymagało pewnych zmian w prawie krajowym. Przede wszystkim można mieć wątpliwości, czy przepisy Kodeksu dotyczące przestępstw przeciwko bezpieczeństwu powszechnemu, a także przepisy ustaw szczególnych ${ }^{57}$ obejmuja wszystkie wypadki przewożenia urządzeń, materiałów, oprogramowania i technologii służących do wytwarzania broni biologicznej, chemicznej atomowej lub służących do wykorzystania w zakresie innej działalności związanej z technologiami nuklearnymi, o których mowa w konwencji. Wobec zasady wyrażonej w art. $16 \S 2$ k.k., w związku z postanowieniami konwencji dotyczącymi wejścia $\mathrm{w}$ porozumienie ${ }^{58}$, ewentualnej rewizji w prawie polskim wymagać może zakres karalnego przygotowania.

Analogiczne uwagi odnoszą się do przyjęcia protokołu pekińskiego. Ponadto jego ratyfikacja wymagała będzie dalszych zmian w Kodeksie karnym w kierunku karalności bezprawnego wykonywania kontroli, a nie wyłącznie przejęcia, kontroli nad statkiem powietrznym. Należałoby też uwzględnić nowe sposoby popełnienia tego przestępstwa określone w protokole.

Przewidziany w aktach pekińskich nowy obowiązek ustanowienia jurysdykcji państwa obywatelstwa sprawcy jest już obecnie zrealizowany przepisami Kodeksu karnego (art. 109 w zw. z art. 111). Akty pekińskie pozwalaja na

\footnotetext{
${ }^{55} \mathrm{~W}$ związku z brakiem uznania pewnych państw praktyka ta miała zapewniać powszechny dostęp do konwencji. Szerzej: Z. Galicki, Konwencja o zwalczaniu bezprawnego zawtadnięcia..., s. 66; J. Rajski, op. cit., s. 716-717.

${ }^{56}$ Zob. uchwała A37-23, w której Zgromadzenie ICAO rekomenduje wszystkim państwom ratyfikację aktów przyjętych podczas konferencji pekińskiej (ICAO Doc 9958).

57 Przede wszystkim ustawy z 29 listopada 2000 r. o obrocie z zagranica towarami, technologiami i usługami o znaczeniu strategicznym dla bezpieczeństwa państwa, a także dla utrzymania międzynarodowego pokoju i bezpieczeństwa (Dz. U. 2004, Nr 229, poz. 2315 ze zm.).

${ }^{58}$ Przy czym konwencja i protokół przewidują alternatywę łączną (either or both) w zakresie karalności wejścia w porozumienie oraz opisanego powyżej pomocnictwa na rzecz grupy.
} 
wprowadzenie dodatkowych jurysdykcji państwa obywatelstwa ofiary przestępstwa lub państwa stałego miejsca zamieszkania sprawcy będącego bezpaństwowcem. Taką możliwość należy poważnie rozważyć. Będzie ona wymagała zmiany ustawy oraz dokonania stosownej notyfikacji. W związku z uregulowanym $\mathrm{w}$ umowach przestępstwem poplecznictwa, $\mathrm{w}$ obliczu przepisów art. 239 § 2-3 Kodeksu karnego, notyfikacji przez Polskę wymagać będa też przesłanki wyłączenia lub złagodzenia odpowiedzialności (wypadki działania na rzecz osoby najbliższej).

Jeżeli chodzi o pozostałe instytucje z konwencji i protokołu, których implementacja ma charakter fakultatywny (ewentualnie zamienny $\mathrm{z}$ innymi rozwiązaniami), to sa one już obecnie znane prawu polskiemu. Zdefiniowane w prezentowanych aktach pomocnictwo na rzecz grupy działającej ze wspólnym zamiarem przestępczym spełnia $\mathrm{w}$ zasadzie znamiona udziału $\mathrm{w}$ zorganizowanej grupie przestępczej lub związku przestępczym albo pomocnictwa $\mathrm{w}$ działalności takiej grupy lub związku. Natomiast przewidziana w dokumentach pekińskich odpowiedzialność osób prawnych i jednostek organizacyjnych niemających osobowości prawnej jest w kraju uregulowana w zasadzie wyłącznie w ustawie z 28 października 2002 r. o odpowiedzialności podmiotów zbiorowych za czyny zabronione pod groźba kary ${ }^{59} \mathrm{i}$ jest ograniczona przesłanką korzyści (w tym także niemajątkowej) odniesionej przez taki podmiot w wyniku popełnienia przestępstwa ${ }^{60}$.

Podsumowując rozważania, warto dodać, że fakt, iż zakres kryminalizacji przewidziany konwencją i protokołem w dużej części jest już w prawie krajowym osiągnięty, nie powinien być argumentem powstrzymującym ratyfikację aktów pekińskich. Polska może być w przyszłości zainteresowana wykorzystaniem nowych instrumentów dotyczących jurysdykcji obywatelstwa ofiary, czy też wykorzystania znanych już instytucji lotniczego prawa karnego w odniesieniu do nowych przestępstw międzynarodowych.

dr Jan Walulik

\section{BEIJING CONVENTION ON CRIMINAL AIR LAW - GENESIS, SUBSTANCE AND RECOMMENDATIONS}

\section{Summary}

The paper deals with criminal air law and its current reform. First, the author summarises the present state of international criminal air law. This includes a review of its general characteristics and of the key provisions of relevant conventions, and their incorporation in national laws. Next, certain drawbacks of regulations regarded to be the prerequisites for the reform are presented. This is followed by a description of the innovative solutions of the acts adopted at the international conference in Beijing in 2010 (i.e. the Beijing Convention and the Beijing Protocol), currently awaiting their entry into force and ratification in Poland. In conclusion, the author makes his own recommendations and remarks regarding the implementation of these acts in Poland and indicates some optional solutions and possible amendments the national criminal law.

\footnotetext{
59 Dz. U. 2012, poz. 768 ze zm.

${ }^{60} \mathrm{Z}$ kolei obecne uregulowania prawa lotniczego dotyczące administracyjnych kar pieniężnych nie znajdą w rozważanym wypadku zastosowania.
} 
Copyright of Journal of Law, Economics and Sociology is the property of Faculty of Law and Administration of Adam Mickiewicz University in Poznan and its content may not be copied or emailed to multiple sites or posted to a listserv without the copyright holder's express written permission. However, users may print, download, or email articles for individual use.

Właścicielem praw autorskich do „Ruchu Prawniczego, Ekonomicznego i Socjologicznego” jest Wydział Prawa i Administracji Uniwersytetu im. Adama Mickiewicza w Poznaniu. Zawartość czasopisma nie może być kopiowana, przesyłana do innych stron internetowych bądź zamieszczana na blogach bez pisemnej zgody wydawcy. Niemniej artykuły można drukować, kopiować lub przesyłać w formie elektronicznej na własny użytek. 